\title{
Cherax quadricarinatus (von Martens) has invaded Indonesian territory west of the Wallace Line: evidences from Java
}

\author{
Jiří Patoka ${ }^{1, *}$, Yusli Wardiatno ${ }^{2}$, Yonvitner $^{2}$, Pavlína Kuř́ková ${ }^{1}$, Miloslav Petrtýl $^{1}$ and Lukáš Kalous ${ }^{1}$ \\ ${ }^{1}$ Department of Zoology and Fisheries, Faculty of Agrobiology, Food and Natural Resources, Czech University of Life Sciences Prague, \\ Kamýcká 129, Prague 165 21, Czech Republic \\ 2 Department of Aquatic Resources Management, Faculty of Fisheries and Marine Science, Bogor Agricultural University, Bogor 16680, \\ Jawa Barat, Indonesia
}

\begin{abstract}
Cherax quadricarinatus (von Martens) (Decapoda: Astacidea: Parastacidae) is commercially exploited and has been intentionally introduced to various tropical and subtropical countries. Once established in the wild, it frequently becomes invasive. In Indonesia, this crayfish is native only to the southern part of the Papua Province. Cherax quadricarinatus is produced in semi-intensive farms for food as well as for ornamental purposes on most of Indonesian territory. We present here the first record of this species from Java, where this crayfish has formed at least two established feral populations. In total, eight subadult and adult crayfish of both sexes were captured in two natural lakes in the city of Bogor, West Java Province. Based on climate match, we suggest that $C$. quadricarinatus has high potential to become established within most of Indonesian territory. As a rapidly growing species with broad tolerance to varying environmental conditions, its spread is expected and it should be viewed as a possible threat to native decapod crustaceans. Detailed monitoring is therefore needed.
\end{abstract}

Keywords: crayfish / biological invasion / redclaw / climate match / Parastacidae

Résumé - Cherax quadricarinatus (von Martens) a envahi le territoire indonésien à l'ouest de la ligne de Wallace : preuves à Java. Cherax quadricarinatus (von Martens) (Décapode : Astacidé : Parastacidé) est exploitée commercialement et a été introduite intentionnellement dans divers pays tropicaux et subtropicaux. Une fois établie dans la nature, elle devient souvent invasive. En Indonésie, cette écrevisse est originaire seulement de la partie sud de la province de Papouasie. Cherax quadricarinatus est produite dans des exploitations semi-intensives pour la consommation, ainsi que pour des fins ornementales sur la plupart des territoires indonésiens. Nous présentons ici le premier signalement de cette espèce à Java, où cette écrevisse a formé au moins deux populations sauvages établies. Au total, huit subadultes et adultes d'écrevisses des deux sexes ont été capturés dans deux lacs naturels dans la ville de Bogor, province de Java Ouest. Basés sur les conditions climatiques, nous suggérons que $C$. quadricarinatus a un fort potentiel pour s'établir dans la plupart des territoires indonésiens. Comme c'est une espèce à croissance rapide avec une large tolérance aux conditions environnementales variables, sa propagation est attendue et elle doit être considérée comme une menace possible pour les crustacés décapodes indigènes. Une surveillance étroite est donc nécessaire.

Mots clés : écrevisse / invasion biologique / écrevisse bleue / climat / Parastacidés

\section{Introduction}

There exist globally many examples of human-mediated introductions of non-native crayfish species, and their negative consequences such as out-competition with native species, disease spread and habitat alternation are widely discussed

\footnotetext{
* Corresponding author: patoka@af.czu.cz
}

(Olden et al., 2006; Coughran et al., 2009; Holdich et al., 2009; Kawai et al., 2009; Buřič et al., 2011; Chucholl, 2016).

The Australian red-claw crayfish or redclaw Cherax quadricarinatus (von Martens) is a large and physically robust omnivorous species with moderate fecundity and broad tolerance to varying environmental conditions (Lin et al., 1999; Jones et al., 2000). It belongs to the Northern group of Cherax crayfish and inhabits streams, billabongs, and lakes in the northern part of the Northern Territory and far north Queensland in Australia and the southern part of New Guinea 
(Munasinghe et al., 2004; Bláha et al., 2016). This species has been successfully introduced to, and has established feral populations within, several tropical and subtropical countries, including Jamaica (Todd, 2002), Mexico (Bortolini et al., 2007; Vega-Villasante et al., 2015), Puerto Rico (Williams Jr et al., 2001), Singapore (Ahyong and Yeo, 2007; Belle and Yeo, 2010), and South Africa (De Moor, 2002). Only one population in the temperate zone has thus far been recorded, that being in Slovenia (Jaklič and Vrezec, 2011). Both aquaculture and the pet trade are regarded as introduction pathways for redclaw (Coughran and Leckie, 2007; Belle et al., 2011; Saoud et al., 2013; Kouba et al., 2014).

Although detailed information about crayfish production in Asian countries other than China are mostly not available, it is known that commercial production of redclaw was started in the late 1980s (Jones et al., 2000; Lawrence and Jones, 2002). Since redclaw is very tolerant to high water temperatures (Tropea et al., 2010) and least adaptable to the low water temperature conditions (Veselý et al., 2015), it has high potential for aquaculture farming in South East Asia; it is easy to breed, easy to feed, has a rapid growth rate, is easy to harvest, is tolerant to crowding and handling, and, finally, has good marketability (New, 2003; Edgerton, 2005). In Indonesia, semi-intensive farms producing redclaw for food and subsequently also for ornamental purpose were established early as 2003 (Edgerton, 2005). Redclaw is one of the most popular crayfish species kept in aquaria (Chucholl, 2013; Papavlasopoulou et al., 2014; Patoka et al., 2014a; Faulkes, 2015). Although Snovsky and Galil (2011) mentioned ornamental production in Israel, Indonesia has been recently identified as the leading exporter of redclaw into Europe via the international pet trade (Patoka et al., 2015).

To date, there has been little information about the possible occurrence of redclaw and its probability to become established outside its area of native distribution, west of the Wallace Line delineating Australian and Southeast Asian fauna. Therefore, we surveyed selected localities in West Java province and ascertained the probability that this crayfish had established feral populations within Indonesian territory.

\section{Materials and methods}

\subsection{Study sites}

Sampling was conducted at two sites: Cilala Lake and Lido Lake, both in Bogor, West Java Province, Indonesia (Fig. 1). This urban area of the city Bogor is located approximately $60 \mathrm{~km}$ south of the national capital of Jakarta.

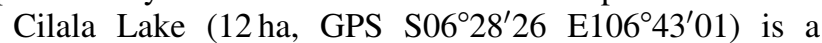
natural lake with muddy bottom, situated at an altitude of 120 masl, with average depth of $1.9 \mathrm{~m}$ and maximum depth of $4.8 \mathrm{~m}$. The lake is fed by groundwater and two small streams. Only one stream, named Ciseeng, flows out of the lake. The area around the lake is densely inhabited and agriculturally cultivated. The lake serves as a water source for surrounding communities and also as fish supply. Common carp (Cyprinus carpio L.) and Mozambique tilapia (Oreochromis mossambicus, Peters) are the most common species exploited for food purposes. Moreover, circa 30 ornamental fish species, such as goldfish (Carassius auratus, L.), black molly (Poecilia sphenops, Valenciennes), and freshwater angelfish

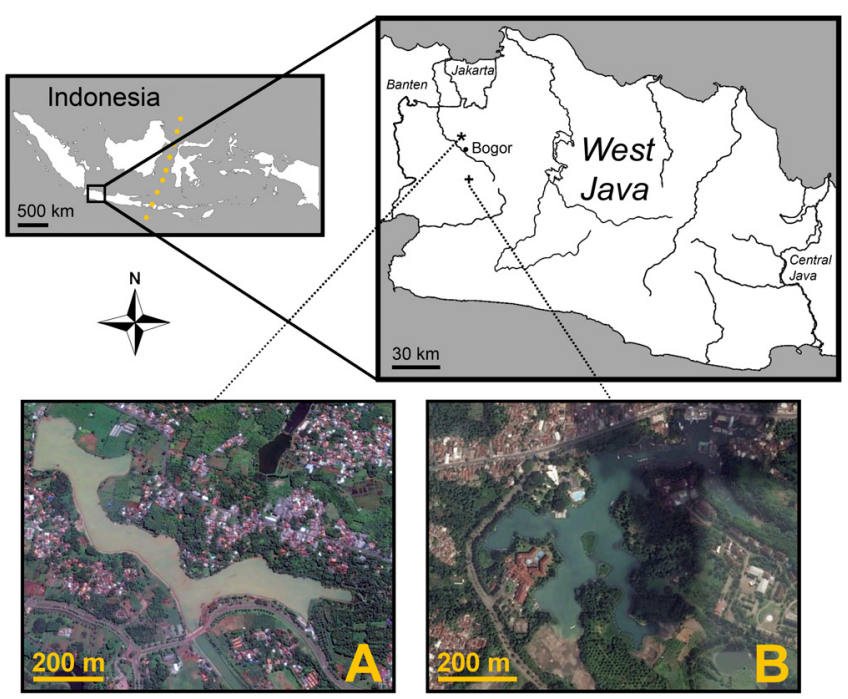

Fig. 1. Map showing localities where Cherax quadricarinatus was collected from natural lakes in Java, Indonesia: Cilala Lake (indicated by black asterisk and letter A); Lido Lake (indicated by black cross and letter B) (adapted from: www.d-maps.com and Google Earth). Yellow dotted is the Wallace Line.

(Pterophyllum scalare, Schultze) are cultured in net cages (Novita, 2013; Novita et al., 2015).

Lido Lake (19.9 ha, GPS S06 $44^{\prime} 38$ E106 $48^{\prime} 31$ ) is a natural lake with muddy bottom, situated at an altitude of 506 masl, with average depth of $9.7 \mathrm{~m}$ and maximum depth of $18.0 \mathrm{~m}$. The lake is fed by groundwater and a small stream from the southwest. The area around the lake is surrounded by paddy fields and houses. Ornamental fish such as goldfish are cultured in net cages near the outlet of the lake (Wardiatno and Krisanti, 2013).

\subsection{Data collection}

Cilala Lake was sampled by line fishing during one night. Lido Lake was sampled also during one night using 10 baited bamboo traps, the method usually used by local fishermen. The traps were baited by meat of freshwater gastropod Pomacea sp. All crayfish were measured immediately after capture and subsequently preserved in pure alcohol or kept alive in aquaria at Bogor Agricultural University. The carapace length was measured from the tip of the rostrum to the posterior end of the carapace. We additionally asked local people living around the lake for information regarding the crayfish's occurrence.

\subsection{Morphological identification}

The morphological identification followed Holthuis (1949) and Souty-Grosset et al. (2006).

\subsection{Molecular analysis}

Due to confusion in taxonomy of some Cherax species (see Austin, 1996; Bláha et al., 2016), we included DNA analysis in to our study. Moreover, the importance of DNA identification was previously highlighted in many non-native crayfish species (e.g. Filipová et al., 2011). 
The morphological identification of each specimen was confirmed by two molecular markers that were amplified by polymerase chain reaction. Selected for identification purposes were genes of mitochondrial cytochrome oxidase subunit I (COI) and 16S ribosomal RNA. We used for the COI gene the universal primer pair LCO1490 (5'-GGTCAACAAATCATAAAGATATTGG-3') and HCO2198 (5'-TAAACTTCAGGGTGACCAAAAAATCA-3') (Folmer et al., 1994) and primer pair 1471 (5'-CCTGTTTANCAAAAACAT-3') and $1472\left(5^{\prime}\right.$-AGATAGAAACCAACCTGG-3') for the 16S gene (Crandall and Fitzpatrick, 1996). The samples were sequenced using the Macrogen sequencing service in the Netherlands (www.macrogen.com). Chromatograms were assembled and checked for potential errors. Edited sequences were aligned using Clustal W, as implemented in the BioEdit software package (Hall, 1999).

\subsection{Climate match}

The climate match between source and target area was computed using the Climatch tool (v.1.0, Invasive Animals Cooperative Research Centre, Bureau of Rural Sciences). This tool was used in previous climate matching of non-native crayfish species (e.g. Chucholl, 2013; Kotovska et al., 2016). Climatic data were obtained from the database of the WordClim project (Hijmans et al., 2005). The region of redclaw's native geographic range (130 meteorological stations) was used (Bláha et al., 2016; Munasinghe et al., 2004) as the source area. The target area was defined as the territory of Indonesia (164 meteorological stations). The territory of the Papua was excluded from evaluation due to native occurrence of the species there. Temperatures during the coldest, warmest, wettest, and driest quarter of the year have been used as variables. In accordance with Kalous et al. (2015) we considered a score $\geq 7.0$ as indicating there to be no environmental barrier to survival.

\section{Results}

In Cilala Lake, we captured 1 male crayfish and 3 females with average carapace length $56.8 \mathrm{~mm}$ and ranging from $31 \mathrm{~mm}$ to $78 \mathrm{~mm}$. In Lido Lake, we caught 1 male and 3 females with average carapace length $53.5 \mathrm{~mm}$ and varying from $34 \mathrm{~mm}$ to $68 \mathrm{~mm}$. All captured individuals were vital and without visible injuries. Subsequently, one berried female (carapace length $42 \mathrm{~mm}$ ) was captured by local fisherman by trap in Lido Lake (Fig. 2).

The crayfish was identified morphologically as $C$. quadricarinatus. All individuals express the same identification characters given in Holthuis (1949) and Souty-Grosset et al. (2006). Four individuals are stored under the numbers JP2016/Y01-04 in the Collection of Aquatic Crustaceans at the Department of Zoology and Fisheries, Czech University of Life Sciences Prague, Czech Republic. Three individuals are stored under the numbers CQB01-03 in the Collection of Aquatic Organisms at the Aquatic Biomolecular Laboratory, Department of Aquatic Resources Management, University of Bogor, Indonesia.

The obtained DNA sequences (COI gene: KX377345, KX377346, KX377347, KX377348; and 16S gene: KX258721, KX258722, KX258723, KX258724) confirmed the morpholog-

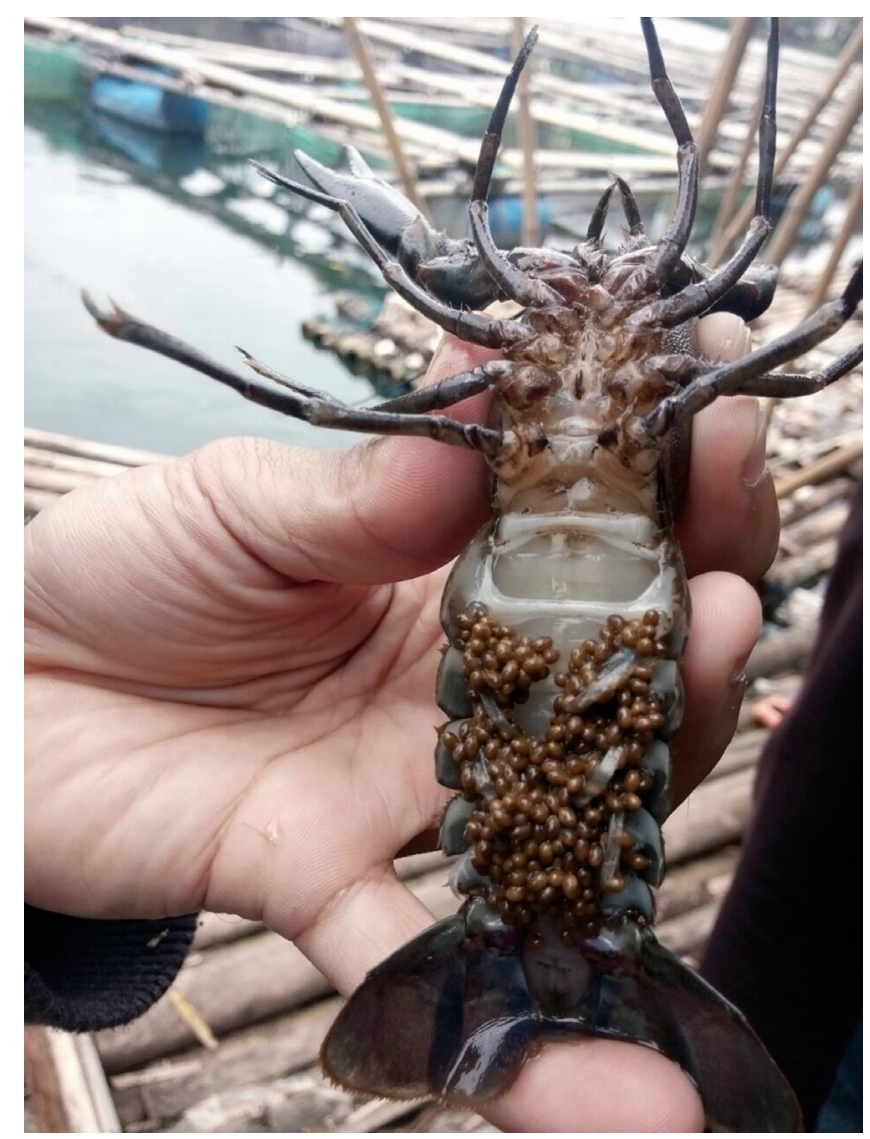

Fig. 2. Berried female captured in Lido Lake.

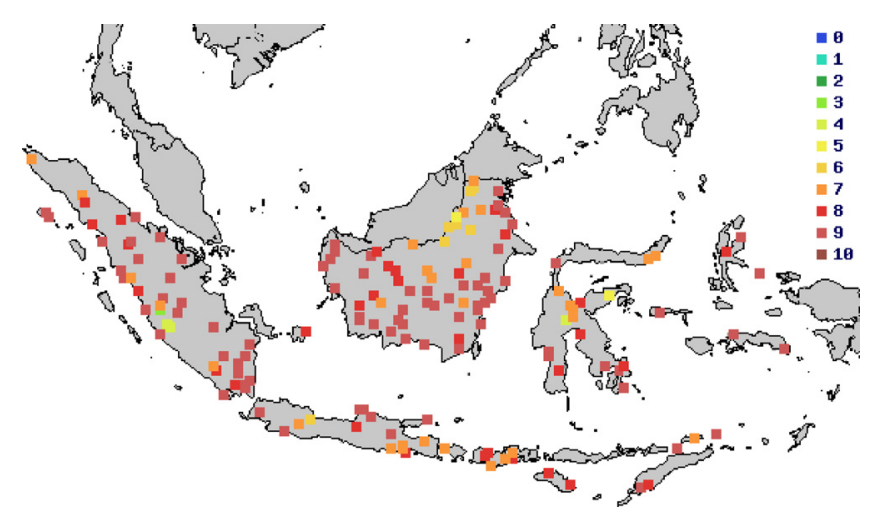

Fig. 3. Map of Indonesia showing the probability for establishment of Cherax quadricarinatus. The Papua Province has been excluded due to the native occurrence of this species (http://data.daff.gov.au:8080/ Climatch/climatch.jsp).

ical identification of the captured crayfish as C. quadricarinatus. The COI and $16 \mathrm{~S}$ fragments obtained matched completely with the publicly available reference sequences of the redclaw from GenBank (acc. nos. KF649850.1 and KJ920762.1).

Based on climate match, redclaw has a high probability to become established within the vast majority of Indonesian territory (Fig. 3). The native redclaw's population occurring in the south of the Papua Province has been identified via processed climate matching as the most adaptable to target area conditions (Fig. 4). 


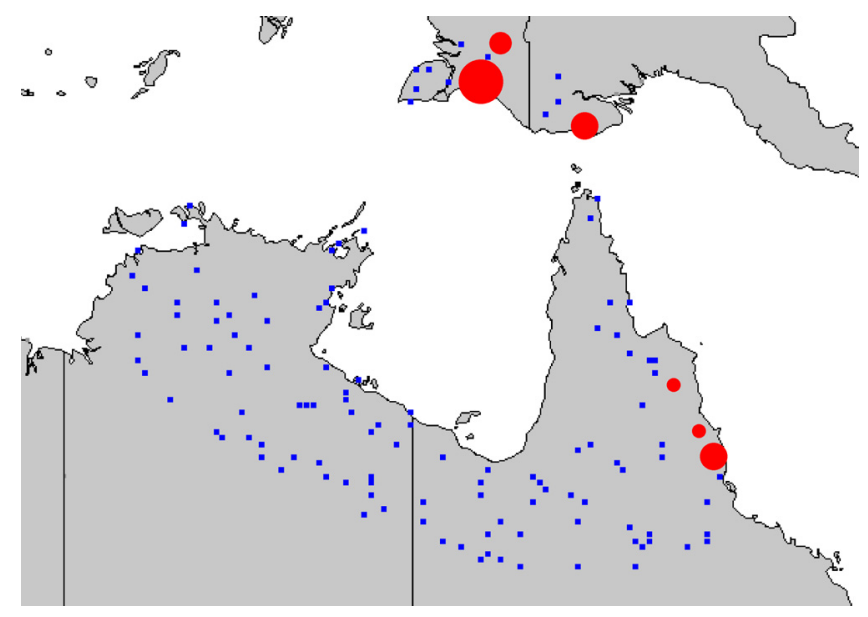

Fig. 4. Map of meteorological stations and potential match to the source region. Blue points indicated stations that were not matching; red points represent matching stations. The area with the greatest climatic similarity within redclaw's native range and rest of Indonesian territory is indicated by the largest red circle (http:// data.daff.gov.au:8080/Climatch/climatch.jsp).

\section{Discussion}

Based on information from local people, we confirmed the occurrence of two populations of redclaw in natural lakes in West Java province (Fig. 1). Although it is known that the species is produced at several semi-intensive farms in Indonesia (Edgerton, 2005), this is the first record from the wild west of the Wallace line in this country. It is not clear whether crayfish have been released intentionally or unintentionally. According to information from the local people, the crayfish are captured and sold for food (Cilala Lake) and as ornamentals (Lido Lake). Since berried females are frequently seen inhabiting the riparian zone and one was captured (Fig. 2), we suggest to consider both populations as established.

Despite low levels of dissolved oxygen and elevated nitrite levels in both lakes due to aquaculture activities (Novita, 2013; Wardiatno and Krisanti, 2013), it seems that poor water quality conditions do not limit local populations of redclaw. This reconfirms the reports of Karplus et al. (1998), Lin et al. (1999), and Saoud et al. (2013), who considered this crayfish species as very adaptable to poor water quality conditions.

Moreover, climatic conditions present no obstacles to successful spreading inasmuch as they are very similar across the vast majority of Indonesian territory and the area of this crayfish's native origin. We identified the redclaw population occurring in the southern part of the Papua Province (Munasinghe et al., 2004) having the highest potential for dispersing when introduced new regions in rest of Indonesia (Fig. 4).

It is well known that introduction of non-native crayfish species can lead to competitive interactions with native species; decline in biomass of macroinvertebrates, macrophytes, periphyton, and certain fish and amphibians due to preying and grazing; food web alterations; the addition of associated symbionts; habitat modification; and disease introductions (Horwitz, 1990; Gherardi, 2007). Although no crayfish species are native to Indonesia with the exception of
West Papua and Papua Provinces, there are many unique freshwater habitats (Vaillant et al., 2011) with occurrence of endemic decapods such as shrimps (e.g. Zitzler and Cai, 2006; von Rintelen et al., 2008) and crabs (Ng, 1989; Ng et al., 2015) which can potentially be threatened by spread of non-native crayfish. A negative influence of redclaw on Javanese biota is therefore expected due to its ability to replace or prey upon native freshwater decapods and through habitat modification (cf. Belle et al., 2011).

We expect possible economic impact to two long-arm shrimps, Macrobrachium dacqueti (Sunier) and Macrobrachium rosenbergii (De Man), which are produced largely in Indonesia (Wowor and $\mathrm{Ng}, 2007$ ). These effects could be manifested by predation, disease transmission and also by habitat alteration. In addition, small freshwater shrimps from the genus Neocaridina cultured and exported from Indonesia in large quantities via the pet trade (Patoka et al., 2016) may be affected. Moreover, redclaw has been identified as a host and vector of various pathogens (e.g. Cannon, 1991; Edgerton and Owens, 1999; Bowater et al., 2002; Saoud et al., 2013) potentially posing a threat to native decapods.

Based on aforementioned information, the release of redclaw into lakes in West Java Province is most likely caused by people's intention for future harvests. This may imply much higher propagule pressure than in countries, where hobbyists are responsible for uncontrolled spreading of kept crayfish in general (Patoka et al., 2014b).

The impact of invasive species in South East Asia is not considered the main environmental problem (Sodhi et al., 2004) inasmuch as the rich biodiversity of the tropical ecosystems minimizes the probability for invaders to become successfully established due to biotic resistance (Rejmánek, 1996). The situation has been changing dramatically in recent years, however, and ever-expanding human-modified landscape creates more vulnerability to biological invasion, especially in the case of freshwater ecosystems (Pelicice et al., 2014). The tropical zone is not only a donor but also a receiver of non-native potentially invasive species, and these may become a threat to local biota within Indonesian territory. In view of these facts, we strongly recommend further detailed monitoring of redclaw to assess its environmental impacts and spread while at the same time working to improve wildlife management (including possible eradication) and relevant local legislation.

Acknowledgements. The study was supported by the project 'CIGA' (No. 20152007) and the Erasmus Mundus project ALFABET (No. 552071). We thank Yuyun Qonita, Agus Alim Hakim and Ali Mashar for their technical help with sample collection. The English was proofread by a nativespeaking editor from English Editorial Services.

\section{References}

Ahyong ST, Yeo DC. 2007. Feral populations of the Australian redclaw crayfish (Cherax quadricarinatus von Martens) in water supply catchments of Singapore. Biol Invasions 9: 943-946.

Austin CM. 1996. Systematics of the freshwater crayfish genus Cherax Erichson (Decapoda: Parastacidae) in northern and eastern Australia: electrophoretic and morphological variation. Aust J Zool 44: 259-296. 
Belle CC, Yeo DC. 2010. New observations of the exotic Australian red-claw crayfish, Cherax quadricarinatus (von Martens, 1868) (Crustacea: Decapoda: Parastactidae) in Singapore. Nat Singap 3: 99-102.

Belle CC, Wong JQ, Yeo DC, et al. 2011. Ornamental trade as a pathway for Australian redclaw crayfish introduction and establishment. Aquat Biol 12: 69-79.

Bláha M, Patoka J, Kozák P, Kouba A. 2016. Unrevealed diversity in New Guinean crayfish species: the evidence from molecular data Integr Zool. Doi:10.1111/1749-4877.12211.

Bortolini JL, Alvarez F, Rodríguez-Almaraz G. 2007. On the presence of the Australian redclaw crayfish, Cherax quadricarinatus, in Mexico. Biol Invasions 9: 615-620.

Bowater RO, Wingfield M, Fisk A, et al. 2002. A parvo-like virus in cultured redclaw crayfish Cherax quadricarinatus from Queensland, Australia. Dis Aquat Organ 50: 79-86.

Buřič M, Hulák M, Kouba A, Petrusek A, Kozák P. 2011. A successful crayfish invader is capable of facultative parthenogenesis: a novel reproductive mode in decapod crustaceans. PLOS ONE 6: e20281.

Cannon LR. 1991. Temnocephalan symbionts of the freshwater crayfish Cherax quadricarinatus from northern Australia. Hydrobiologia 227: 341-347.

Chucholl C. 2013. Invaders for sale: trade and determinants of introduction of ornamental freshwater crayfish. Biol Invasions 15: $125-141$.

Chucholl C. 2016. The bad and the super-bad: prioritising the threat of six invasive alien to three imperilled native crayfishes. Biol Invasions. Doi:10.1007/s10530-016-1141-2.

Coughran J, Leckie S. 2007. Invasion of a New South Wales stream by the tropical crayfish, Cherax quadricarinatus (von Martens). In: Lunney D, Eby P, Hutchings P, Burgin S, eds. Pest or Guest: the zoology of overabundance. Mosman, NSW, Australia: Royal Zoological Society of New South Wales, 40-46.

Coughran J, McCormack R, Daly G. 2009. Translocation of the Yabby Cherax destructor into eastern drainages of New South Wales, Australia. Aust Zool 35: 100-103.

Crandall KA, Fitzpatrick JJ. 1996. Crayfish molecular systematics: using a combination of procedures to estimate phylogeny. Syst Biol 45: $1-26$

De Moor I. 2002. Potential impacts of alien freshwater crayfish in South Africa. Afr J Aquat Sci 27: 125-139.

Edgerton BF. 2005. Freshwater crayfish production for poverty alleviation. World Aquac 36: 48-64.

Edgerton BF, Owens L. 1999. Histopathological surveys of the redclaw freshwater crayfish, Cherax quadricarinatus, in Australia. Aquaculture 180: 23-40.

Faulkes Z. 2015. The global trade in crayfish as pets. Crustacean Res 44: 75-92.

Filipová L, Grandjean F, Chucholl C, Soes DM, Petrusek A. 2011. Identification of exotic North American crayfish in Europe by DNA barcoding. Knowl Manag Aquat Ecosyst 401: 11.

Folmer O, Black M, Hoeh W, Lutz R, Vrijenhoek R. 1994. DNA primers for amplification of mitochondrial Cytochrome $\mathrm{C}$ oxidase subunit I from diverse metazoan invertebrates. Mol Mar Biol Biotech 3: 294-299.

Gherardi F. 2007. Understanding the impact of invasive crayfish. In: Gherardi F, ed. Biological invaders in inland waters: profiles, distribution, and threats. Dordrecht, Netherlands: Springer, 507-542.

Hall TA. 1999. BioEdit: a user-friendly biological sequence alignment editor and analysis program for Windows 95/98/NT. Nucleic Acids Symp Ser 41: 95-98.
Hijmans RJ, Cameron SE, Parra JL, Jones PG, Jarvis A. 2005. Very high resolution interpolated climate surfaces for global land areas. Int J Climatol 25: 1965-1978.

Holdich DM, Reynolds JD, Souty-Grosset C, Sibley P. 2009. A review of the ever increasing threat to European crayfish from non-indigenous crayfish species. Knowl Manag Aquat Ecosyst 394-395: 11.

Holthuis LB. 1949. Decapoda Macrura, with a revision of the New Guinea Parastacidae. Zoological Results of the Dutch New Guinea Expedition 1939, No. 3. Nova Guinea 5: 289-328.

Horwitz P. 1990. The translocation of freshwater crayfish in Australia: potential impact, the need for control and global relevance. Biol Conserv 54: 291-305.

Jaklič M, Vrezec A. 2011. The first tropical alien crayfish species in European waters: the redclaw Cherax quadricarinatus (Von Martens, 1868) (Decapoda, Parastacidae). Crustaceana 84: 651-665.

Jones CM, McPhee C, Ruscoe IM. 2000. A review of genetic improvement in growth rate in redclaw crayfish Cherax quadricarinatus (von Martens) (Decapoda: Parastacidae). Aquac Res 31: 61-67.

Kalous L, Patoka J, Kopecký O. 2015. European hub for invaders: risk assessment of freshwater ornamental fish exported from the Czech Republic. Acta Ichthyol Piscat 45: 239-245.

Karplus I, Zoran M, Milstein A, et al. 1998. Culture of the Australian red-claw crayfish (Cherax quadricarinatus) in Israel: III. Survival in earthen ponds under ambient winter temperatures. Aquaculture 166: 259-267.

Kawai T, Scholtz G, Morioka S, Ramanamandimby F, Lukhaup C, Hanamura Y. 2009. Parthenogenetic alien crayfish (Decapoda: Cambaridae) spreading in Madagascar. J Crustacean Biol 29: 562-567.

Kotovska G, Khrystenko D, Patoka J, Kouba A. 2016. East European crayfish stocks at risk: arrival of non-indigenous crayfish species. Knowl Manag Aquat Ecosyst 417: 37.

Kouba A, Petrusek A, Kozák P. 2014. Continental-wide distribution of crayfish species in Europe: update and maps. Knowl Manag Aquat Ecosyst 413: 05.

Lawrence C, Jones C. 2002. Cherax. In: Holdich D, ed. Biology of freshwater crayfish. London: Blackwell Science, 635-669.

Lin T, Liu F, Liao I. 1999. Experiment on adaptation of Australian crayfish to selected environmental factors. J Taiwan Fish Res 7: $73-85$.

Munasinghe D, Burridge C, Austin C. 2004. Molecular phylogeny and zoogeography of the freshwater crayfish genus Cherax Erichson (Decapoda: Parastacidae) in Australia. Biol J Linn Soc 81: 553-563.

New M. 2003. Responsible aquaculture: Is this a special challenge for developing countries? World Aquac 34: 26-31.

Ng PK. 1989. Terrathelphusa, a new genus of semiterrestrial freshwater crabs from Borneo and Java (Crustacea: Decapoda: Brachyura: Sundathelphusidae). Raffles B Zool 37: 116-131.

$\mathrm{Ng}$ PK, Schubart CD, Lukhaup C. 2015. New species of "vampire crabs" (Geosesarma De Man, 1892) from central Java, Indonesia, and the identity of Sesarma (Geosesarma) nodulifera De Man, 1892 (Crustacea, Brachyura, Thoracotremata, Sesarmidae). Raffles B Zool 63: 3-13.

Novita M. 2013. Penentuan Daya Dukung untuk Kegiatan Keramba Ikan Hias di Situ Cilala, Kabupaten Bogor, Jawa Barat. Indonesia: Institut Pertanian Bogor, 41 p.

Novita M, Soewardi K, Pratiwi NTM. 2015. Penentuan Daya Dukung Perairan untuk Perikanan Alami (Studi Kasus: Situ Cilala, Kabupaten Bogor). Jurnal Ilmu Pertanian Indonesia 20: 66-71. 
Olden JD, McCarthy JM, Maxted JT, Fetzer WW, Vander Zanden MJ. 2006. The rapid spread of rusty crayfish (Orconectes rusticus) with observations on native crayfish declines in Wisconsin (USA) over the past 130 years. Biol Invasions 8: 1621-1628.

Papavlasopoulou I, Perdikaris C, Vardakas L, Paschos I. 2014. Enemy at the gates: introduction potential of non-indigenous freshwater crayfish in Greece via the aquarium trade. Centr Eur J Biol 9: 1-8.

Patoka J, Kalous L, Kopecký O. 2014a. Risk assessment of the crayfish pet trade based on data from the Czech Republic. Biol Invasions 16: 2489-2494.

Patoka J, Petrtýl M, Kalous L. 2014b. Garden ponds as potential introduction pathway of ornamental crayfish. Knowl Manag Aquat Ecosyst 414: 13.

Patoka J, Kalous L, Kopecký O. 2015. Imports of ornamental crayfish: the first decade from the Czech Republic's perspective. Knowl Manag Aquat Ecosyst 416: 4.

Patoka J, Bláha M, Devetter M, Rylková K, Čadková Z, Kalous L. 2016. Aquarium hitchhikers: attached commensals imported with freshwater shrimps via the pet trade. Biol Invasions 18: 457-461.

Pelicice FM, Vitule JRS, Lima Junior DP, Orsi ML, Agostinho AA. 2014. A serious new threat to Brazilian freshwater ecosystems: the naturalization of nonnative fish by decree. Conserv Lett 7: 55-60.

Rejmánek M. 1996. Species richness and resistance to invasions. In: Orians GH, Dirzo R, Cushman JH, eds. Biodiversity and ecosystem processes in tropical forests. Berlin Heidelberg: Springer-Verlag, $153-172$.

Saoud IP, Ghanawi J, Thompson KR, Webster CD. 2013. A review of the culture and diseases of redclaw crayfish Cherax quadricarinatus (von Martens 1868). J World Aquacult Soc 44: 1-29.

Snovsky G, Galil BS. 2011. The Australian redclaw crayfish Cherax quadricarinatus (von Martens, 1868) (Crustacea: Decapoda: Parastactidae) in the Sea of Galilee, Israel. Aquat Inv 6: S29-S31.

Sodhi NS, Koh LP, Brook BW, Ng PK. 2004. Southeast Asian biodiversity: an impending disaster. Trends Ecol Evol 19: 654-660.
Souty-Grosset C, Holdich DM, Noël PY, Reynolds J, Haffner P. 2006. Atlas of crayfish in Europe. Paris, France: Muséum National d'Histoire Naturelle, 187 p.

Todd S. 2002. The introduced red claw crayfish in Jamaica. Jamaica: Institute of Jamaica, $6 \mathrm{p}$.

Tropea C, Piazza Y, Greco LSL. 2010. Effect of long-term exposure to high temperature on survival, growth and reproductive parameters of the "redclaw" crayfish Cherax quadricarinatus. Aquaculture 302: 49-56.

Vaillant JJ, Haffner GD, Cristescu ME. 2011. The ancient lakes of Indonesia: towards integrated research on speciation. Integr Comp Biol 51: 634-643.

Vega-Villasante F, Ávalos-Aguilar JJ, Nolasco-Soria H, et al. 2015. Wild populations of the invasive Australian red claw crayfish Cherax quadricarinatus (Crustacea, Decapoda) near the northern coast of Jalisco, Mexico: a new fishing and profitable resource. Latin Am J Aquat Res 43: 781-785.

Veselý L, Buřič M, Kouba A. 2015. Hardy exotics species in temperate zone: can "warm water" crayfish invaders establish regardless of low temperatures? Sci Rep 5: 16340.

von Rintelen K, Karge A, Klotz W. 2008. News from a small island first record of a freshwater shrimp (Decapoda, Atyidae, Caridina) from Peleng, Banggai Islands, Indonesia. J Nat Hist 42: 2243-2256.

Wardiatno Y, Krisanti M. 2013. The vertical dynamics of larval chironomids on artificial substrates in Lake Lido (Bogor, Indonesia). Trop Life Sci Res 24: 13-29.

Williams Jr EH, Bunkley-Williams L, Lilyestrom CG, Ortiz-Corps EA. 2001. A review of recent introductions of aquatic invertebrates in Puerto Rico and implications for the management of nonindigenous species. Caribb J Sci 37: 246-251.

Wowor D, Ng PK. 2007. The giant freshwater prawns of the Macrobrachium rosenbergii species group (Crustacea: Decapoda: Caridea: Palaemonidae). Raffles B Zool 55: 321-336.

Zitzler K, Cai Y. 2006. Caridina spongicola, new species, a freshwater shrimp (Crustacea: Decapoda: Atyidae) from the ancient Malili lake system of Sulawesi, Indonesia. Raffles B Zool 54: 271-276.

Cite this article as: Patoka J, Wardiatno Y, Yonvitner, Kuř́ková P, Petrtýl M, Kalous L. 2016. Cherax quadricarinatus (von Martens) has invaded Indonesian territory west of the Wallace Line: evidences from Java. Knowl. Manag. Aquat. Ecosyst., 417, 39. 